\title{
COL1A2/PLAG1 Fusion Gene
}

National Cancer Institute

\section{Source}

National Cancer Institute. COL1A2/PLAG1 Fusion Gene. NCI Thesaurus. Code C101053.

A fusion gene that results from a chromosomal translocation $t(7 ; 8)(p 22 ; q 13)$ which fuses the $5^{\prime}$ promoter region of the COL1A2 gene upstream of the entire coding region of the PLAG1 gene. This rearrangement is associated with both aberrant expression of the transcription factor zinc finger protein PLAG1 and lipoblastoma. 